\title{
Conservation In Practice
}

\author{
LLOYD T. CARMICHAEL, REGINA
}

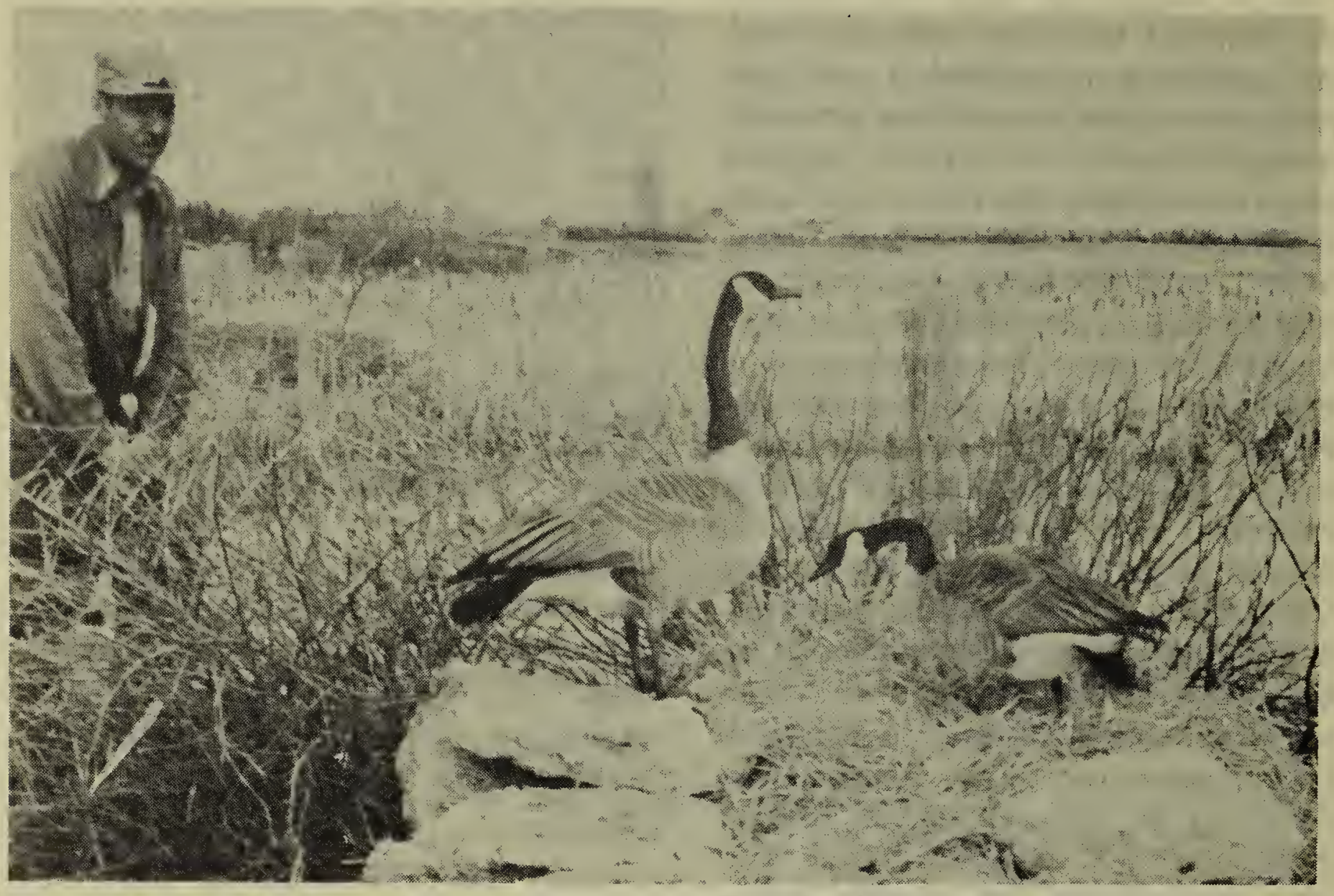

Undisturbed by Mr. Bard's presence, Hiawatha stands vigilant as Madame Queen prepares the nest.

70 many casual observers the word "museum" is synonymous with stuffed birds and beasts, with cases of mounted insects, with collections of shells, fossils and arrowheads, with old muskets and older Indian relics. It is a record of the ages, a close-up study of the dead, a panorama of yesteryear. For some museums, in a certain sense, that may be true, but the Provincial Museum at Regina is different. Its beautiful habitat scenes with backgrounds that only a master artist could paint add a living and a vital touch. The whole set-up is different-it is different because the director, Fred Bard, and those who work with him are vitally interested in the out-of-doors and in the conservation of all forms of wildlife that bring profit and pleasure to each of us.

Fred does not only advocate conservation but he practises what he preaches. Besides his city home, he has a small farmstead of some four acres in extent, bordering on Wascana Marsh, about two and a half miles from the centre of Regina. He calls it his field study station. During most summer evenings and on holidays he is there, not only looking after his fruit shrubs and garden-that is incidental-but in observing the thousands of birds which visit there and in making plans for their protection. The whole area is a naturalist's paradise. Over seventy species of birds raise their young in that vicinity and 
at the present time there are thirty species making their homes on his four acre station.

It was my idea to write more fully about this birdland paradise, but for this issue, space will not allow. I hope to do so for the next issue after visiting the area several more times. For the present I wish to confine my remarks to two new visitors-two Canada Geese, Madame Queen and Hiawatha. Did I say two geese, I should have said seven, for on May 30, two goslings arrived followed on Coronation Day by three more. What an appropriate name their mother has!

It all happened when on April. 7th, Ralph Stueck, farmer-naturalist of Abernethy, presented Mr. Bard with a mated pair of these birds. They are now eight years old. Among his friends, Mr. Stueck is affectionately known as Hiawatha Stueck and I have a strong suspicion that "daddy" goose derived his name from that source.

Immediately Mr. Bard fenced off a suitable area, as protection against roving dogs and other predators, and erected a suitable nest site on the bank of a deep dug-out which extends from the shore of his property. Soon the birds were at home, even although the weather turned very cold and at one time there was two or three inches of ice on the surrounding water. The first egg was laid on April 24 and Queen settled down to the serious business of incubation on May 2. While she was on her nest she lay flat with neck outstretched at the slightest sound of approaching danger, while Hiawatha would advance gallantly towards the direction of the sound, his bill opened to its full extent, hissing loudly as it moved. Nothing must disturb that nest. These two are mated for life, and he is very determined that nothing shall break that partnership, or mar the happiness of that home.

Surrounded by water birds of many species, all protected from danger, this family lives in a very congenial environment. At times it is a noisy but always a busy place, for here are three colonies of Yellow-headed Blackbirds, displaying their brilliant colors and joining in constant conversational croaking and gurgling of harsh rough voices. Nearby is a colony of Common Terns, many gracefully circling about-hovering on beating wings one moment, and the next dropping like plummets with sparkling splashes. Their shrill cry blends with that of the music of the marshes. Then there are two or three colonies of Black Terns, scores of which are incubating their eggs on low, wet and seemingly floating masses of reeds and other debris.

There is also a colony of the Longbilled Marsh Wren. Near the tops of the reeds and rushes are their numerous ball-like nests of dead cat-tail leaves and grass, only a small number of which seem to be occupied-the rest a sham. From their solitary reconnaissance stalks they "launch themselves into the air some 10 or 15 feet and gurgle out rippling melodious little songs as they gently sink on fluttering wings to other stations."

Ducks of many species, the Coot, the Sora and Virginia Rail, Wilson Phalarope, Pied-billed Grebe and the Bittern are all there now, busy and beautiful as they busy themselves with their nesting operations; but above all Mr. Bard is chiefly interested in the encouragement and protection of those colonies of birds whose presence adds so much to the fascination of the marsh.

Such is the home of Madame Queen and Hiawatha and the five young (Continued on Poge 27) 


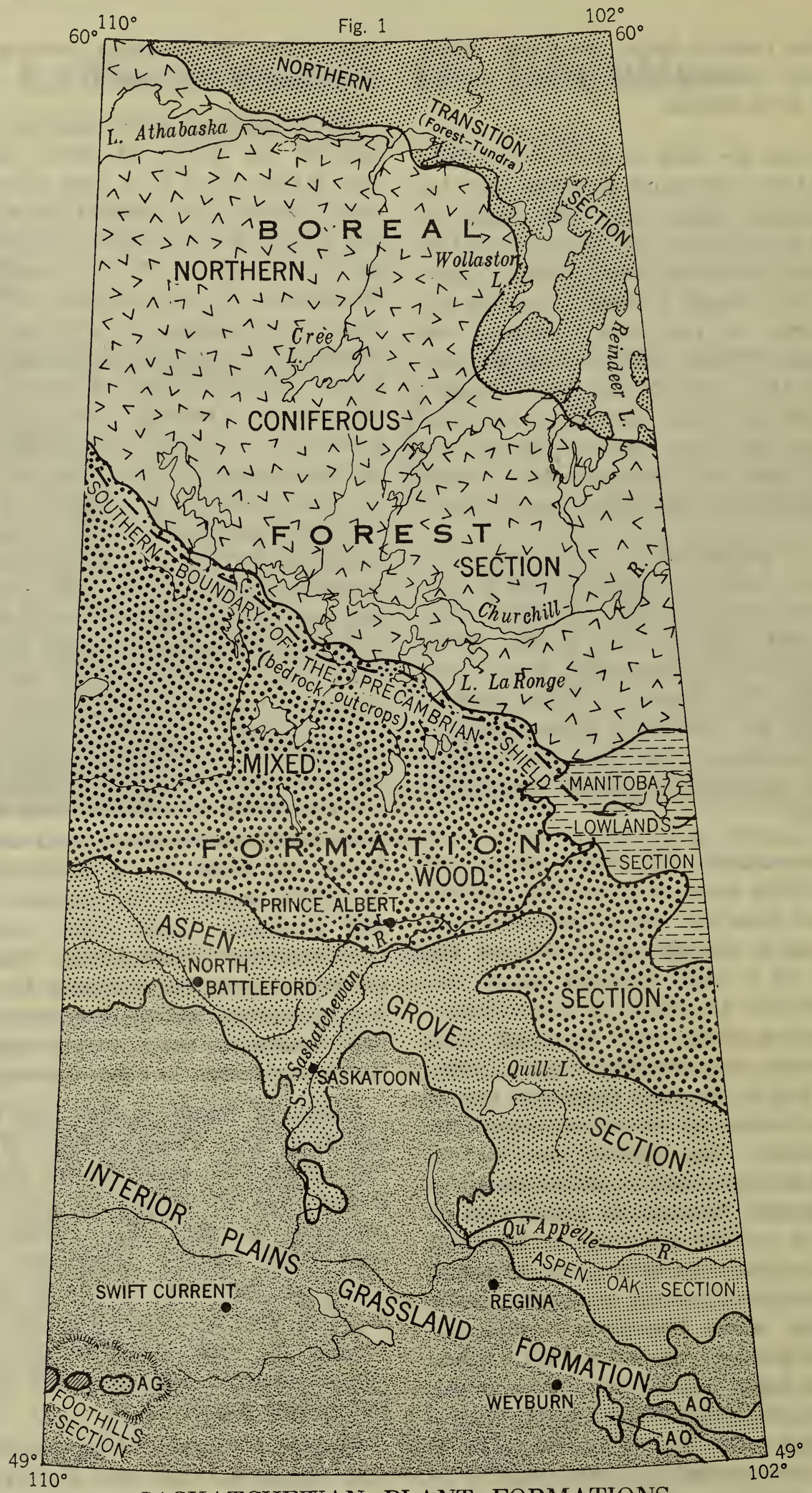




\section{HIDDEN VALLEY SANCTUARY}

(Continued from Page 17)

from her babies, the young ones scattering out of sight in the thick bush. A glimpse can often be caught of the high-jumping White-tail Deer, sometimes a fine buck with horns still in velvet, sometimes a doe with a beautiful little spotted fawn, might cross the path ahead of you.

Saskatoon berries, in season, grow in abundance. There are sweet wild strawberries besides the trails, and raspberries in the thickets and as darkness falls owls call whur-who-oo and rabbits stir in the sheltering dusk of tangled chokecherry thickets.

On the high hills in spring, tiny Mossphlox and Townsendia bloom, and later come the brilliant wax-like flowers of the Prickly Pear and Purple Ball Cactus. June brings many thousands of Roses, Wood Anemone and Shooting Star. Western Red Lilies can be found in the coulees in summer, and in the autumn of the year, come Bergamot, Asters and Goldenrod.

It might be a good thing if such sanctuaries for wild creatures, for trees, and for wild flowers, were established in many parts of our province. Perhaps in your own district there is a valley, slough or stretch of lakeshore, that could be preserved in its natural state for the enjoyment of all of those who are interested in the beauties of nature.

\section{CONSERVATION IN PRACTISE}

(Continued from Page 21)

goslings. This fall the goslings will be allowed to migrate. It is hoped that they will return again, if even for a brief stay.

This worthy project is a striking example of conservation in action. The Canada Goose has sadly diminished in numbers over much of its common territory in Saskatchewan through expanded farming observations and marsh draining projects. There seems no good reason that many others could not start similar conservation projects. All that is required is enthusiasm, a pair of geese and full co-operation of all who live near or visit the protected areas.

\section{THE SAW-LOC BIRD-BOX}

CAN BE MADE IN SUITABLE SIZES FOR TPEE SWALLOWS, BLUEBIPDS, WPENS AND CHICKADEES-
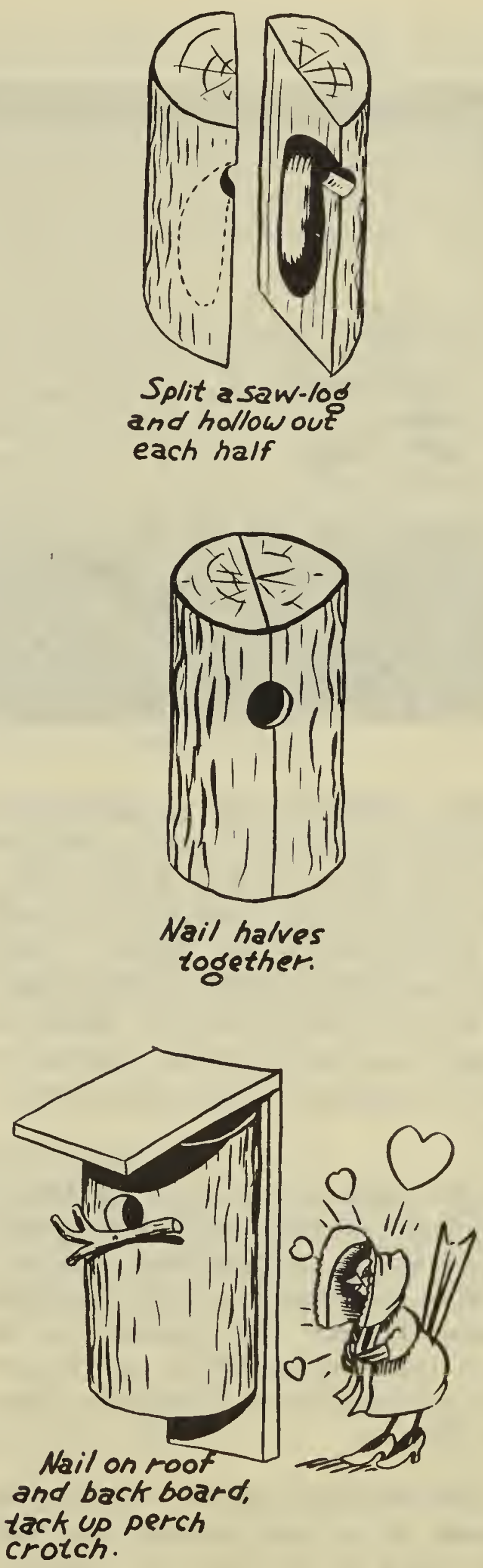